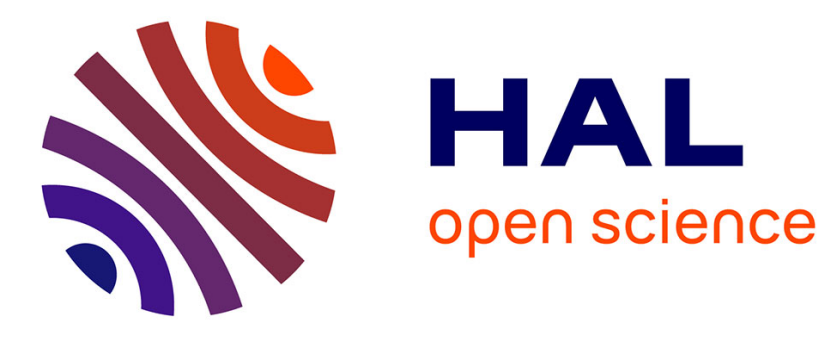

\title{
Addition and elimination reactions of 2 in ruthenaborane clusters: A computational study
}

Hassan Rabaâ, Sundargopal Ghosh, Dage Sundholm, Jean-François Halet, Jean-Yves Saillard

\section{- To cite this version:}

Hassan Rabaâ, Sundargopal Ghosh, Dage Sundholm, Jean-François Halet, Jean-Yves Saillard. Addition and elimination reactions of 2 in ruthenaborane clusters: A computational study. Journal of Organometallic Chemistry, 2014, 761, pp.1 - 9. 10.1016/j.jorganchem.2014.03.001 . hal-01017039v2

\section{HAL Id: hal-01017039 \\ https://hal.science/hal-01017039v2}

Submitted on 2 Jul 2014

HAL is a multi-disciplinary open access archive for the deposit and dissemination of scientific research documents, whether they are published or not. The documents may come from teaching and research institutions in France or abroad, or from public or private research centers.
L'archive ouverte pluridisciplinaire HAL, est destinée au dépôt et à la diffusion de documents scientifiques de niveau recherche, publiés ou non, émanant des établissements d'enseignement et de recherche français ou étrangers, des laboratoires publics ou privés. 


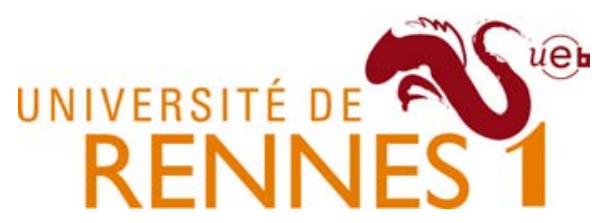

This is the author's final draft post-refeering (post-print)

Find more peer-reviewed articles on our open access repository:

http://hal-univ-rennes1.archives-ouvertes.fr/ 


\title{
Addition and elimination reactions of $\mathrm{H}_{2}$ in ruthenaborane clusters: $\mathrm{A}$ computational study
}

\author{
Hassan Rabaâ ${ }^{\mathrm{a}, *}$, Sundargopal Ghosh ${ }^{\mathrm{b}}$, Dage Sundholm ${ }^{\mathrm{c}}$, Jean-François Halet ${ }^{\mathrm{d}, \mathrm{e}}$, \\ Jean-Yves Saillard ${ }^{\mathrm{d}, \mathrm{e}}$
}

a Département de Chimie, ESCTM, Université Ibn Tofail, P.O. Box. 133, Kénitra 14000, Morocco

${ }^{\mathrm{b}}$ Department of Chemistry, Indian Institute of Technology Madras, Chennai 600 036, India

${ }^{\mathrm{c}}$ Department of Chemistry, P.O.B. 55 (A.I. Virtasen aukio 1), FIN-00014, University of Helsinki, Finland

${ }^{\mathrm{d}}$ Institut des Sciences Chimiques de Rennes, UMR 6226 CNRS-Université de Rennes 1, F-35042 Rennes Cedex, France

e Université Européenne de Bretagne, 5 Boulevard Laënnec, F-35000 Rennes, France

\section{A B S T R A C T}

Ruthenaborane clusters have been modelled by performing density functional theory calculations using the B3LYP functional. The calculations gain insights into hydrogen storage and the $\mathrm{H}-\mathrm{H}$ bond activation by ruthenaboranes. To study the nature of the chemical bond of $\mathrm{H}_{2}$ molecules attached to ruthenaboranes, we carried out structural optimizations for different ruthenaborane clusters and determined transition state structures for their hydrogenation addition/elimination reactions. Calculations of the reaction pathways yielded different transition-state structures involving molecular hydrogen bonded to the cluster or formation of metal hydrides. The $\mathrm{H}-\mathrm{H}$ bond of $\mathrm{H}_{2}$ seems to be activated by the ruthenaborane clusters as activation energies of $24-42 \mathrm{kcal} / \mathrm{mol}$ were calculated for the $\mathrm{H}_{2}$ addition reaction. The calculated Gibbs free energy for the $\mathrm{H}_{2}$ addition reaction is $14-27 \mathrm{kcal} / \mathrm{mol}$. The calculated activation energies and the molecular structures of the $\left[\left(\mathrm{C}_{5} \mathrm{Me}_{5}\right) \mathrm{Ru}_{2} \mathrm{~B}_{10} \mathrm{H}_{16}\right],\left[\left(\mathrm{C}_{5} \mathrm{Me}_{5}\right) \mathrm{Ru}_{2} \mathrm{~B}_{8} \mathrm{H}_{14}\right]$ and $\left[\left(\mathrm{C}_{5} \mathrm{Me}_{5}\right)\right.$ $\mathrm{Ru}_{2} \mathrm{~B}_{8} \mathrm{H}_{12}$ ] clusters with different degree of hydrogenation are compared. The mechanisms of the $\mathrm{H}_{2}$ addition and elimination reactions of the studied clusters suggest that they might be useful as hydrogen storage materials due to their ability to activate the $\mathrm{H}-\mathrm{H}$ bond. They also serve as an example of the ability of hypoelectronic metallaboranes to reversibly or irreversibly bind hydrogen.

\section{Introduction}

During the last decade, storage of molecular hydrogen has become an important research field in industry as well as in academia [1-6]. Several of the fundamental and applied studies have focused on the use of metal hydrides as materials for hydrogen storage [2]. Research efforts have been put on the development of new materials with tunable thermodynamic and kinetic properties with the aim of improving the hydrogenation-dehydrogenation properties of hydrogen-storage materials [1-3,5]. The main challenge is to store hydrogen and to use it as industrial battery fuel in combustion engines by employing borohydrides or metal hydrides such as $\mathrm{MgH}_{2}$ and $\mathrm{LiNH}_{2}$, considered as clean energy technologies [2-6]. Some prerequisites for useful recyclable hydrogen-storage materials are fast hydrogen uptake and release reactions as well

\footnotetext{
* Corresponding author. Tel.: +212 537375506 .

E-mail address: hrabaa@yahoo.com (H. Rabaâ).
}

as high structural stability during the repeated hydrogen recycling process. In addition, the hydrogen storage material must not be too expensive to be useful in large scale applications [6]. Recent studies have focused on mixtures of complex metal hydrides as potential hydrogen storage materials. Yang et al. found that ternary mixtures of $\mathrm{MgH}_{2}, \mathrm{LiNH}_{2}$ and $\mathrm{LiBH}_{4}$ have increased the hydrogen release as compared to binary mixtures of these compounds [7]. The magnesium borohydride $\operatorname{Mg}\left(\mathrm{BH}_{4}\right)_{2}$ is also a promising material for hydrogen storage because of its high gravimetric storage capacity of 15.0 mass\% $\mathrm{H}_{2}[3,6-13]$.

The enthalpy of a reversible reaction of dihydrogen uptake/ release of a metal hydride material should be lower than $\sim 20 \mathrm{kcal} /$ mol of $\mathrm{H}_{2}$ assuming moderate heating [4]. This thermodynamical condition does not preclude the necessity for a low activation energy allowing the reaction to proceed under moderate temperature.

In previous studies [14,15], it was discovered that some electrondeficient metallaboranes have the ability to bind a very large amount of hydrogen. It was suggested that reversible dihydrogen uptake by such clusters under very mild conditions should be 
possible [3,8-17] making them a promising starting point for designing new hydrogen storage materials [3,11,13-19].

The activation of the $\mathrm{H}-\mathrm{H}$ bond of $\mathrm{H}_{2}$ is analysed in this study, as a continuation on previous studies where it was shown that an electron-deficient coordination mode seems to be responsible for the activation of $\mathrm{H}-\mathrm{H}$ bonds [21]. The activation of $\sigma(\mathrm{H}-\mathrm{H}, \mathrm{C}-\mathrm{H}$ and $\mathrm{B}-\mathrm{H}$ ) bonds is of central interest in homogeneous or heterogeneous catalysis, where it has been the leitmotiv in the past decades [19-22]. The chemistry of the dihydrogen bonding including aspects of hydrogen storage has been reviewed by Kubas [20]. Studies on bis-dihydrogen-ruthenium complexes such as $\left(\mathrm{PCy}_{3}\right)_{2} \mathrm{RuH}_{2}\left(\mathrm{H}_{2}\right)_{2}$ demonstrated that there is an excellent balance between $\sigma$-donation and $\pi$ back-donation when binding labile dihydrogen ligands to the complex [23-25].

In this work, we study the $\mathrm{H}_{2}$ addition/elimination reactions on the hydrogen-rich ruthenaborane $\mathrm{Cp}_{2}{ }_{2} \mathrm{Ru}_{2} \mathrm{~B}_{10} \mathrm{H}_{16}$ (1) [14], $\mathrm{Cp}_{2}{ }_{2} \mathrm{Ru}_{2} \mathrm{~B}_{8} \mathrm{H}_{14}(\mathbf{2})$ and $\mathrm{Cp}^{*}{ }_{2} \mathrm{Ru}_{2} \mathrm{~B}_{8} \mathrm{H}_{12}$ (3) $\left(\mathrm{Cp}^{*}=\mathrm{C}_{5} \mathrm{Me}_{5}\right)$ [16] clusters experimentally characterized by one of us. The aim of this computational study is to provide a deeper understanding of the electronic structures of these metallaboranes and to predict how molecular hydrogen can coordinate to the cluster cage. Reaction coordinate profiles of the hydrogenation and dehydrogenation mechanism have been computationally studied at the B3LYP level of theory for estimating the energy barriers and the Gibbs free energy of the reactions and for predicting the feasibility of $\mathrm{H}_{2}$ addition/elimination reactions.

\section{Computational methods}

Theoretical calculations were performed with the Gaussian 09 series of programs [26] at the density functional theory (DFT) level using the B3LYP functional [27-29]. To reduce computational efforts, the $\mathrm{C}_{5} \mathrm{Me}_{5}\left(\mathrm{Cp}^{*}\right)$ ligands (see Chart 1 ) were replaced by $\mathrm{C}_{5} \mathrm{H}_{5}$ (Cp) (see Fig. 1).

The LANL2DZ relativistic pseudo-potential (ECP) were used for the ruthenium and the $6-311 \mathrm{G}++(\mathrm{d}, \mathrm{p})$ basis sets for the $\mathrm{H}, \mathrm{B}$ and $\mathrm{C}$ atoms. Harmonic vibrational frequencies were calculated for each cluster to characterize the stationary points on the potential energy surface. All stationary points obtained in the structure optimizations were found to be minima on the potential energy surface. The geometry optimizations were performed on spin-singlet states without any symmetry constraints. Transition-state (TS) structures were obtained by using the synchronous transit-guided quasi-Newton (STQN) method developed by Schlegel et al. as implemented in Gaussian 09 $[30,31]$. Using the intrinsic reaction coordinates (IRC) procedure, we checked that the transition states connect the relevant reactants and products [31]. Gibbs free energies were calculated by considering the entropy contributions obtained in the vibration frequency calculations.

Solvent effects on the activation energy were analysed by performing single-point calculations using the polarizable continuum model (PCM) model [32] and a dielectric constant $(\varepsilon)$ of 2.374 corresponding to toluene.

\section{Results and discussion}

The structure of $\mathrm{Cp}^{*}{ }_{2} \mathrm{Ru}_{2} \mathrm{~B}_{10} \mathrm{H}_{16}$ (1) shown in Chart 1 , is of $C_{2 \mathrm{v}}$ symmetry. Its $\mathrm{B}_{10}$ framework has been described as deriving from a truncated tetrahedron having two missing vertices and of which two hexagonal faces are capped by the two metals atoms [14]. Whereas for this type of architecture one may expect a count of 17skeletal-electron pair (sep) [33,34], the formal electron count of (1) is only 14 sep. Such an electron deficiency with respect to the standard cluster electron counting rules is not uncommon in this family of metallaboranes and has been rationalized in previous studies [17,33]. In addition, each of the ten boron atoms of (1) are linked to one terminal hydrogen and there are six hydrogens bridging boron atoms.

The experimental metrical data of the synthesized cluster $\mathrm{Cp}_{2}{ }_{2} \mathrm{Ru}_{2} \mathrm{~B}_{10} \mathrm{H}_{16}(\mathbf{1})$ are compared to the optimized bond distances of the $C_{2 v}$ model $\mathrm{Cp}_{2} \mathrm{Ru}_{2} \mathrm{~B}_{10} \mathrm{H}_{16}(\mathbf{A})$ model in Table 1 . The numbering of the atoms is shown in Chart 1 . The calculated $\mathrm{Ru}-\mathrm{Ru}^{\prime}$ distance of $4.105 \AA$ is $5 \mathrm{pm}$ longer than the experimental one of $4.057 \AA$ [14]. The average $\mathrm{B}-\mathrm{B}$ and $\mathrm{Ru}-\mathrm{B}$ bond lengths of $1.844 \AA$ and $2.191 \AA$ are $2 \mathrm{pm}$ and $5 \mathrm{pm}$ longer than the experimental values, respectively. The six $\mathrm{Ru}-\mathrm{B}$ bond lengths are in the range $2.155-2.266 \AA$ and the mean distance between $\mathrm{Ru}$ and the six carbons of the $\mathrm{Cp}$ ring is $2.351 \AA$. The somewhat longer bond distances obtained in the calculations are not quite unexpected since the employed computational level tends to overestimate bond lengths [35,36].

The molecular orbital diagram of $\mathbf{A}$ is shown in the middle of Fig. 2. The highest occupied molecular orbital (HOMO) is mostly localized on the metal atoms. The lowest unoccupied molecular orbital (LUMO) is separated from the HOMO by $4.31 \mathrm{eV}$ at the B3LYP level. This large HOMO-LUMO gap is consistent with the stability of the 14-sep cluster 1 . The LUMO $\left(3 a_{1}\right)$ as shown in Fig. 3 is extended all over the $\mathrm{B}_{10} \mathrm{H}_{16}$ moiety, whereas the HOMO $\left(2 \mathrm{a}_{1}\right)$ is mainly localized on the metal atoms (see Fig. 2). The plot analysis indicates that the LUMO has a weak metal-ligand antibonding character with $67 \%$ on the borons and $33 \%$ on $\mathrm{M}-\mathrm{Cp}$ moieties whereas the HOMO exhibits significantly more metallic character than the LUMO. The HOMO and the LUMO play a central role in the $\mathrm{H}_{2}$ elimination/addition reactions as discussed in the next section.

\section{Reaction path for $\mathrm{H}_{2}$ elimination in $\boldsymbol{A}$}

A large number of isomers can be envisaged by eliminating one $\mathrm{H}_{2}$ molecule from $\mathbf{A}$. The energetically most stable $\mathrm{Cp}_{2} \mathrm{Ru}_{2} \mathrm{~B}_{10} \mathrm{H}_{14}$ cluster (see $\mathbf{B}$ in Fig. 3 ) corresponds to the elimination of the two adjacent hydrogen atoms $\mathrm{H} 15$ and $\mathrm{H} 16$ bridging the $\mathrm{B} 5-\mathrm{B} 6$ and B6-B7 bonds, respectively. The optimized bond distances of the structure B are given in Table 1. The elimination of H15 and H16 leads to changes of about $10 \mathrm{pm}$ in the $\mathrm{B} 6-\mathrm{B} 7$ and $\mathrm{B} 7-\mathrm{B} 8$ distances, whereas the B5-B6 and B9-B10 distances are 3 pm longer in $\mathbf{B}$ than in $\mathbf{A}$. The $\mathrm{Ru}-\mathrm{B}$ distances are only slightly affected by the $\mathrm{H}_{2}$ elimination (see Table 1 ).

The molecular orbital diagram of $\mathbf{B}$ in the left side of Fig. 3 shows a large HOMO-LUMO gap of $4.01 \mathrm{eV}$. The wide HOMO-LUMO gap indicates that $\mathbf{B}$ is a stable compound, even though it has two hydrogen atoms less and its 13 sep maintain the $\mathbf{A}$ structure.

The STQN method was employed to determine the reaction pathway between $\mathbf{A}$ and $\mathbf{B}$. The STNQ calculation found one transition state TS1 with one imaginary frequency (see Fig. 3). The starting point for the STQN was obtained by adding a dihydrogen molecule to B far away from the cluster. The STQN calculation converges to TS1 which has a short $\mathrm{H} 11-\mathrm{H} 12$ bond distance of $0.801 \AA$ bridging the $\mathrm{B} 1-\mathrm{B} 2$ and $\mathrm{B} 4-\mathrm{B} 5$ atoms. For TS1, the B1-B2 and $\mathrm{B} 4-\mathrm{B} 5$ bonds are $2.368 \AA$ and $1.981 \AA$ respectively. These bonds are significantly longer than for $\mathbf{B}$, whereas the $\mathrm{B} 7-\mathrm{B} 8$ bond shrinks to $1.678 \AA$. For TS1, the $\mathrm{B} 1 \mathrm{H} 11$ and $\mathrm{B} 2 \mathrm{H} 12$ bonds are $2.066 \AA$ and $1.538 \AA$. The $\mathrm{Ru}-\mathrm{Ru}^{\prime}$ bond distance is practically unchanged (see Table 1 ). TS1 has also a large HOMO-LUMO gap of $3.95 \mathrm{eV}$.

The energy profile for the elimination reaction of $\mathrm{H}_{2}$ from $\mathbf{A}$ yielding B was computed via the IRC procedure (see Fig. 4). The calculated energy barrier of $28 \mathrm{kcal} / \mathrm{mol}$ is somewhat smaller than the energy barrier of $32 \mathrm{kcal} / \mathrm{mol}$ previously estimated for the reaction $\mathrm{Cp}_{2} \mathrm{Re}_{2} \mathrm{~B}_{6} \mathrm{H}_{10}+\mathrm{H}_{2}$ [15]. 


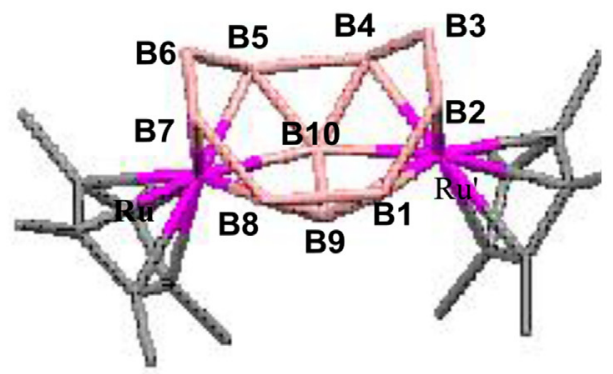

(1)

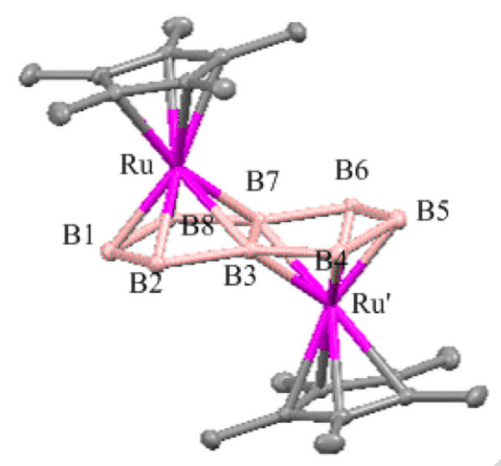

(2)

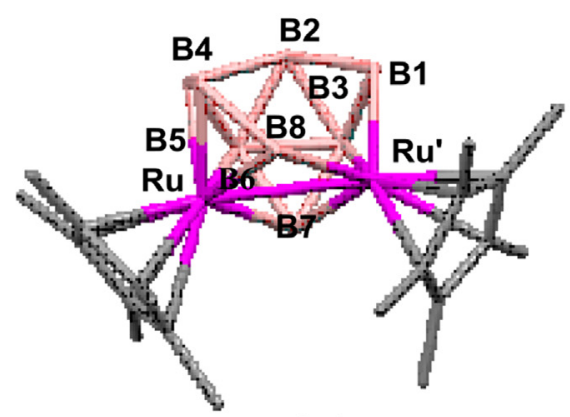

(3)

Chart 1. Labelling of the atoms for the studied clusters: $\left[\mathrm{Cp}_{2}{ }_{2} \mathrm{Ru}_{2} \mathrm{~B}_{10} \mathrm{H}_{16}\right](\mathbf{1}),\left[\mathrm{Cp}_{2}{ }_{2} \mathrm{Ru}_{2} \mathrm{~B}_{8} \mathrm{H}_{14}\right](\mathbf{2})$ and $\left[\mathrm{Cp}^{*}{ }_{2} \mathrm{Ru}_{2} \mathrm{~B}_{8} \mathrm{H}_{12}\right](\mathbf{3})$.

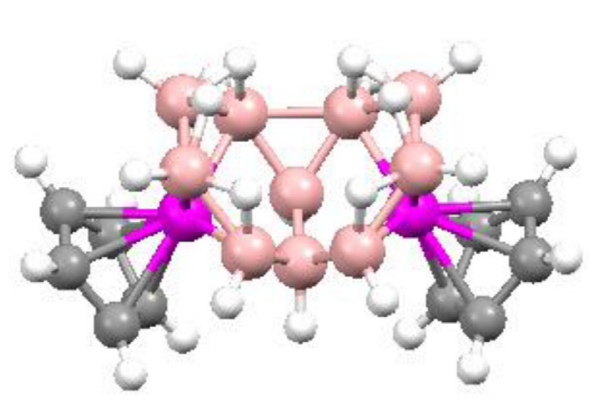

(A)

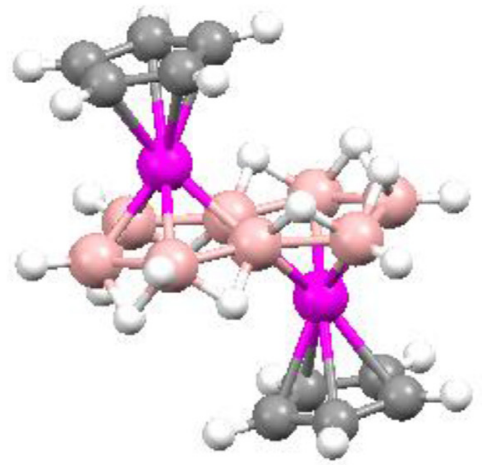

(B)

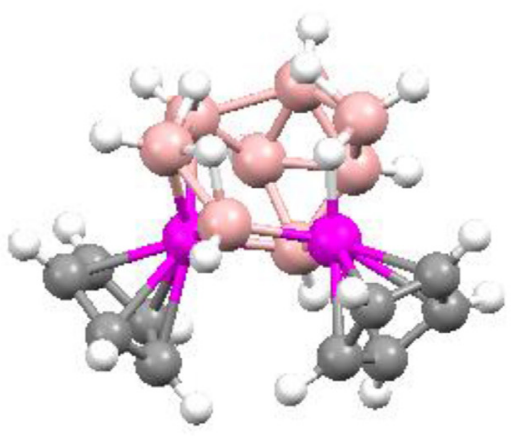

(C)

Fig. 1. Molecular structures of the studied model clusters: $\left[\mathrm{Cp}_{2} \mathrm{Ru}_{2} \mathrm{~B}_{10} \mathrm{H}_{16}\right](\mathbf{A}),\left[\mathrm{Cp}_{2} \mathrm{Ru}_{2} \mathrm{~B}_{8} \mathrm{H}_{14}\right](\mathbf{B})$ and $\left[\mathrm{Cp}_{2} \mathrm{Ru}_{2} \mathrm{~B}_{8} \mathrm{H}_{12}\right](\mathbf{C})$. The ruthenium atoms are shown in red, boron atoms are in pink, carbon atoms are in grey and hydrogen atoms are in white. (For interpretation of the references to colour in this figure legend, the reader is referred to the web version of this article.) 
Table 1

Computed bond lengths ( $\AA$ ) for A, B, C, TS1, TS2, and TS3 (see Chart 1 for atom numbering). Experimental values for 1 are given in parentheses for a comparison with A.

\begin{tabular}{|c|c|c|c|c|c|c|}
\hline Distances & A & B & C & TS1 $(A \rightarrow B)$ & TS2 $(A \rightarrow C)$ & TS3 $(A \rightarrow C)$ \\
\hline B1-B2 & 1.835 (1.794) & 1.831 & 1.849 & 2.368 & 1.824 & 1.867 \\
\hline B2-B3 & $1.818(1.788)$ & 1.823 & 1.788 & 1.829 & 1.814 & 1.842 \\
\hline B3-B4 & 1.835 (1.799) & 1.834 & 1.999 & 1.823 & 1.855 & 1.815 \\
\hline B4-B5 & 1.975 (1.966) & 1.973 & 2.134 & 1.981 & 1.894 & 2.195 \\
\hline B5-B6 & 1.835 (1.795) & 1.867 & 2.457 & 1.852 & 2.124 & 1.842 \\
\hline B6-B7 & $1.816(1.796)$ & 1.705 & 1.821 & 1.823 & 1.822 & 1.839 \\
\hline B7-B8 & $1.835(1.816)$ & 1.736 & 1.821 & 1.678 & 1.825 & 1.832 \\
\hline B9-B10 & $1.773(1.772)$ & 1.800 & 1.813 & 1.783 & 1.824 & 1.702 \\
\hline $\mathrm{Ru}-\mathrm{B} 5$ & $2.223(2.192)$ & 2.257 & 2.297 & 2.198 & 3.164 & 2.255 \\
\hline $\mathrm{Ru}-\mathrm{B} 6$ & $2.155(2.127)$ & 2.117 & 2.300 & 2.154 & 2.153 & 2.168 \\
\hline $\mathrm{Ru}-\mathrm{B} 7$ & $2.155(2.137)$ & 2.148 & 2.200 & 2.239 & 2.143 & 2.125 \\
\hline $\mathrm{Ru}-\mathrm{B} 8$ & $2.223(2.118)$ & 2.161 & 2.215 & 2.252 & 2.208 & 2.242 \\
\hline $\mathrm{Ru}-\mathrm{B} 9$ & $2.266(2.249)$ & 2.279 & 2.223 & 2.232 & 2.195 & 2.815 \\
\hline $\mathrm{Ru}-\mathrm{B} 10$ & $2.266(2.240)$ & 2.245 & 2.192 & 2.224 & 2.362 & 2.364 \\
\hline $\mathrm{Ru}-\mathrm{C}(\mathrm{Cp})$ & $2.351(2.276)$ & 2.331 & 2.355 & 2.342 & 2.321 & 2.312 \\
\hline $\mathrm{Ru}^{\prime}-\mathrm{B} 1$ & $2.223(2.192)$ & 2.235 & 2.265 & 2.159 & 2.243 & 2.229 \\
\hline $\mathrm{Ru}^{\prime}-\mathrm{B} 2$ & $2.155(2.128)$ & 2.152 & 2.193 & 2.105 & 2.154 & 2.139 \\
\hline $\mathrm{Ru}^{\prime}-\mathrm{B} 3$ & $2.228(2.137)$ & 2.158 & 2.184 & 2.177 & 2.161 & 2.146 \\
\hline $\mathrm{Ru}^{\prime}-\mathrm{B} 4$ & $2.228(2.135)$ & 2.227 & 2.371 & 2.240 & 2.208 & 2.301 \\
\hline $\mathrm{Ru}^{\prime}-\mathrm{B} 9$ & 2. $266(2.255)$ & 2.258 & 2.357 & 2.389 & 2.362 & 2.481 \\
\hline $\mathrm{Ru}^{\prime}-\mathrm{B} 10$ & $2.266(2.246)$ & 2.266 & 2.567 & 2.351 & 2.194 & 3.129 \\
\hline $\mathrm{Ru}^{\prime}-\mathrm{C}(\mathrm{Cp})$ & 2. $349(2.276)$ & 2.351 & 2.341 & 2.345 & 2.331 & 2.341 \\
\hline B1-H11 & 1.374 (1.309) & 1.361 & 1.377 & 2.067 & 1.277 & 1.392 \\
\hline $\mathrm{B} 2-\mathrm{H} 12$ & $1.356(1.325)$ & 1.361 & 1.347 & 1.538 & 1.331 & 1.353 \\
\hline B6-H13 & $1.356(1.333)$ & 1.359 & 1.418 & 1.334 & 1.357 & 1.299 \\
\hline B7-H14 & $1.316(1.225)$ & 1.303 & 1.366 & - & 1.278 & 1.302 \\
\hline $\mathrm{H} 11-\mathrm{H} 12$ & $1.912(1.879)$ & 1.945 & 1.939 & 0.801 & 1.845 & 1.955 \\
\hline $\mathrm{H} 13-\mathrm{H} 14$ & $1.942(1.832)$ & - & 1.944 & & 1.932 & 1.957 \\
\hline B4-H15 & $1.237(1.223)$ & - & 1.342 & - & 1.336 & 1. \\
\hline B5-H16 & $1.333(1.321)$ & - & 1.341 & - & 1.343 & 1.406 \\
\hline B5-H17 & - & - & 1.191 & - & 1.252 & 1.197 \\
\hline B6-H18 & - & - & 1.186 & - & 2.471 & - \\
\hline $\mathrm{Ru}^{\prime}-\mathrm{H} 15$ & $2.809(2.811)$ & - & 2.896 & - & 2.901 & 1.729 \\
\hline $\mathrm{Ru}-\mathrm{H} 16$ & $2.836(2.809)$ & - & 2.990 & - & 2.891 & 1.917 \\
\hline $\mathrm{Ru}-\mathrm{H} 17$ & - & - & 2.878 & - & 2.652 & 1.740 \\
\hline $\mathrm{Ru}^{\prime}-\mathrm{H} 18$ & - & - & 2.878 & - & 1.997 & 1.690 \\
\hline H15-H16 & $2.057(2.061)$ & - & 2.167 & - & 1.969 & 1.969 \\
\hline $\mathrm{H} 17-\mathrm{H} 18$ & - & - & 1.798 & - & 1.026 & 3.381 \\
\hline $\mathrm{Ru}-\mathrm{Ru}^{\prime}$ & $4.105(4.057)$ & 4.064 & 4.264 & 4.077 & 4.206 & 4.929 \\
\hline
\end{tabular}

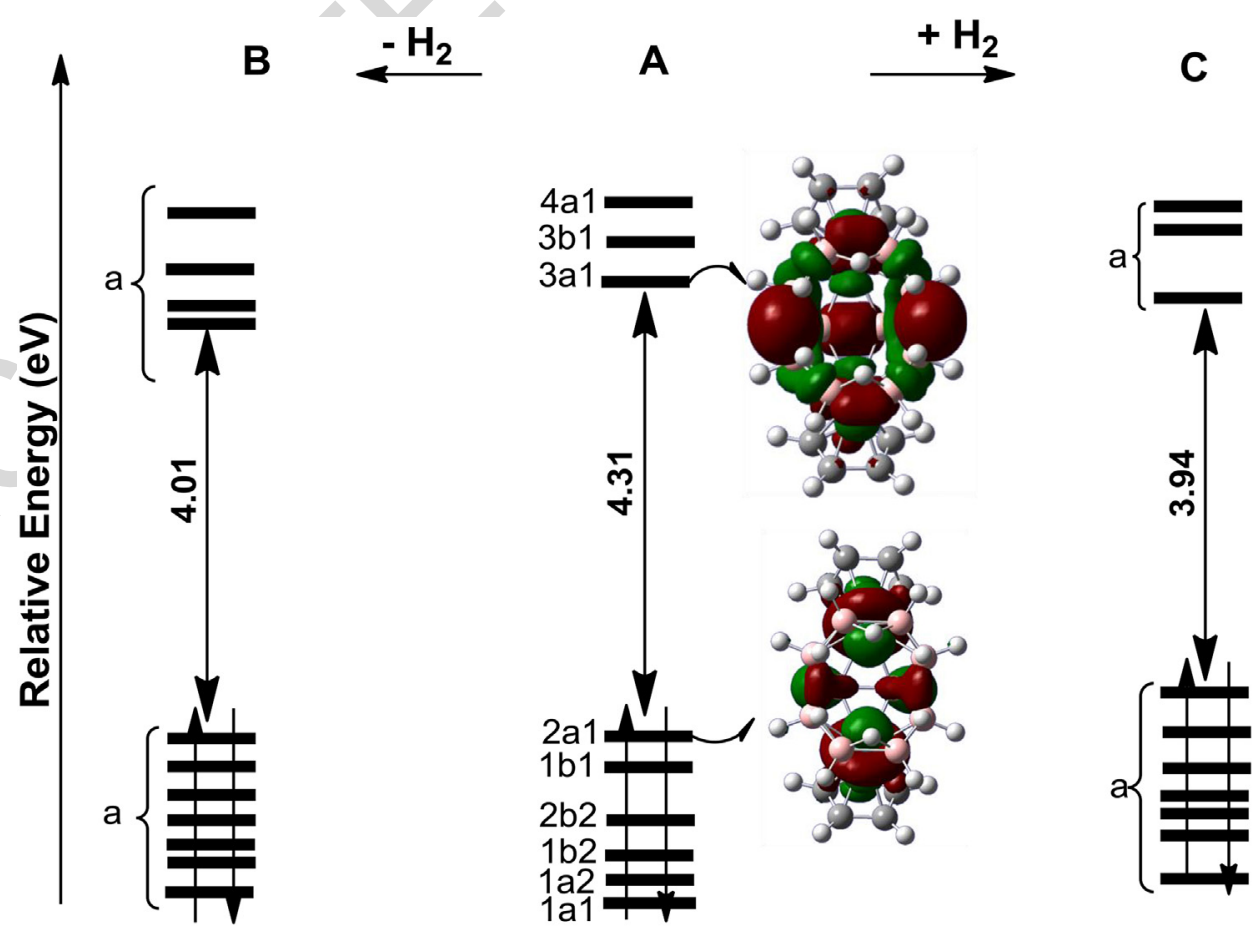

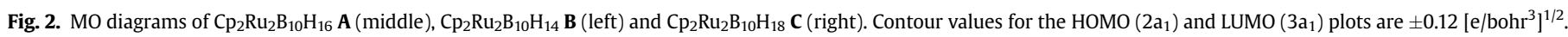




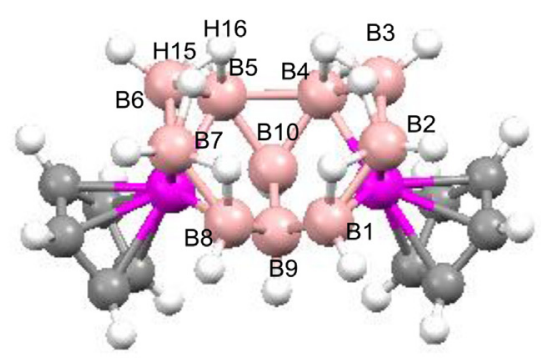

(A)
$-\mathrm{H}_{2}$

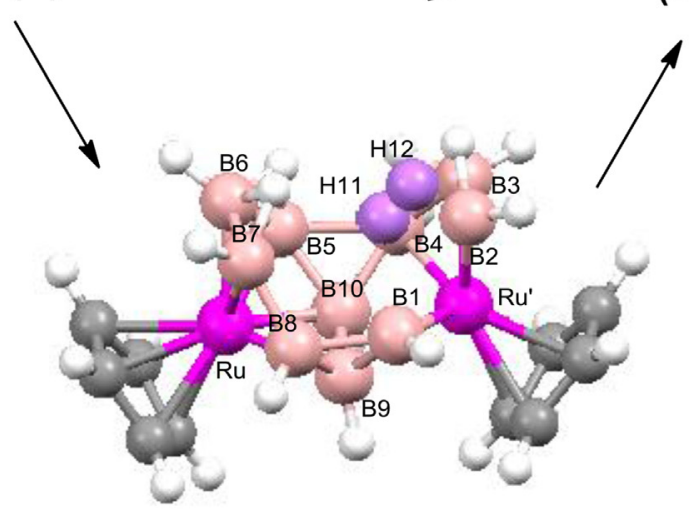

(B)

(TS1)

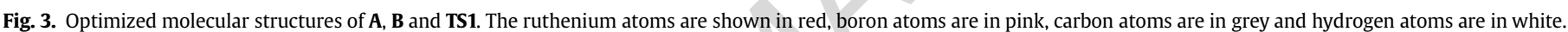

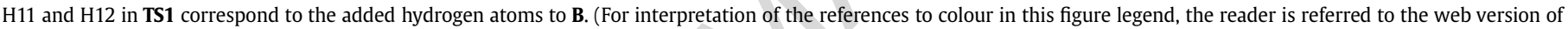
this article.)

\section{Reaction path for addition $\mathrm{H}_{2}$ to $\boldsymbol{A}$}

The reaction pathway for the addition of $\mathrm{H}_{2}$ to $\mathbf{A}$ has also been studied. A dihydrogen molecule was added randomly at practically an infinite distance from $\mathbf{A}$. The optimization yielded $\mathrm{Cp}_{2} \mathrm{Ru}_{2} \mathrm{~B}_{10} \mathrm{H}_{18}$ (C) which is a stable energy minimum with a large HOMO-LUMO gap of $3.94 \mathrm{eV}$. The molecular structure of $\mathbf{C}$ is shown in Fig. 5 and the most relevant bond distances are listed in Table 1 . In the structure one sees that the terminal atoms $\mathrm{H} 17$ and $\mathrm{H} 18$ are bound to $\mathrm{B} 5$ and $\mathrm{B} 8$, respectively. The $\mathrm{Ru}-\mathrm{B}$ and $\mathrm{B}-\mathrm{B}$ bond lengths change

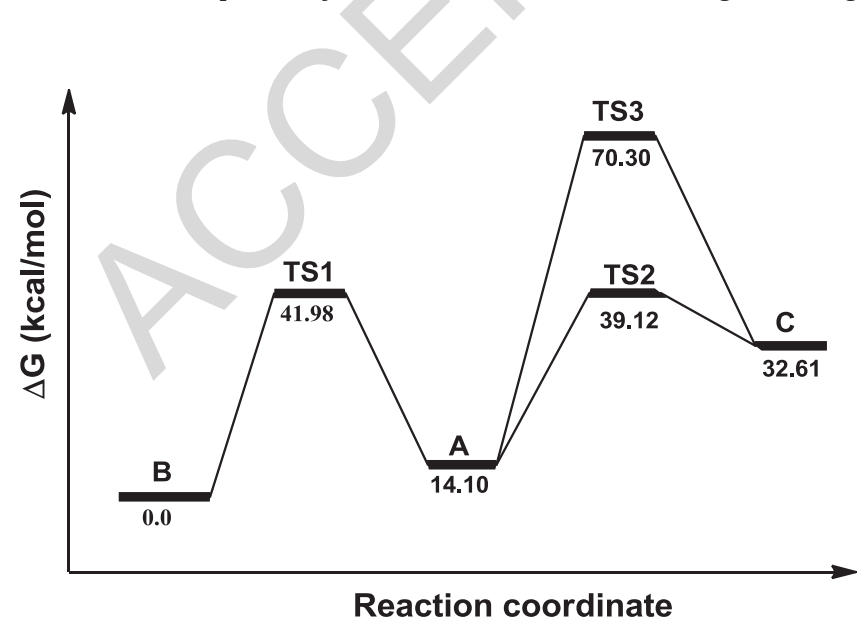

Fig. 4. Energy profile of the hydrogenation. The relative energies of the reactants products of $\mathbf{A}, \mathbf{B}$ and $\mathbf{C}$ through the dehydrogenation in $\mathbf{B} \rightarrow \mathbf{A}$ (left side) and for hydrogenation in $\mathbf{A} \rightarrow \mathbf{C}$ processes (right side). The transition states (TS1, TS2 and TS3) are given. significantly upon addition of $\mathrm{H}_{2}$ to $\mathrm{A}$. The $\mathrm{Ru}-\mathrm{B} 6$ bond is elongated by $30 \mathrm{pm}$ to $2.456 \AA$ which changes the metal coordination. The $\mathrm{Ru}-\mathrm{Ru}^{\prime}$ distance increases by $16 \mathrm{pm}$ to $4.264 \AA$ and the $\mathrm{B} 5-\mathrm{B} 6$ bond breaks as the distance is $2.457 \AA$. In C, the long distance of $1.798 \AA$ between the two incoming hydrogen ( $\mathrm{H} 17$ and $\mathrm{H} 18)$ indicates that the $\mathrm{H}-\mathrm{H}$ bond dissociates. The $\mathrm{Ru}^{\prime}-\mathrm{B} 10$ distance of $2.567 \AA$ is much longer than in $\mathbf{A}$ and $\mathbf{B}$. The structural changes occur mainly in the borane cage leading to its opening upon $\mathrm{H}_{2}$ addition.

By using the IRC procedure, we found transitions states (TS2 and TS3) that connect $\mathbf{A}$ and $\mathbf{C}$, both with large HOMO-LUMO gaps of $4.03 \mathrm{eV}$ and $3.02 \mathrm{eV}$, respectively. Their optimized bond distances are listed in Table 1 . TS2 has a short bond distance of $1.026 \AA$ between the hydrogen atoms of the incoming $\mathrm{H}_{2}$ molecule ( $\mathrm{H} 17$ and $\mathrm{H} 18)$ which has $\eta^{2}$ coordination to B9. The B9-H17 and B9-H18 distances are $1.332 \AA$ and $1.319 \AA$, respectively, as also observed in Kubas' complexes [19]. The B5-B6 bond of $2.124 \AA$ is longer than for A. TS2 is $6.5 \mathrm{kcal} / \mathrm{mol}$ above $\mathbf{C}$. The Gibbs activation energy for the A $+\mathrm{H}_{2}$ to $\mathbf{C}$ through $\mathbf{T S 2}$ is $25 \mathrm{kcal} / \mathrm{mol}$. The second transition state (TS3) has metal hydride bonds, $\mathrm{Ru}^{\prime}-\mathrm{H} 18$ and $\mathrm{Ru}-\mathrm{H} 17$ distances of $1.690 \AA$ and $1.740 \AA$, respectively. In TS3, the B4-B5 distance of $2.195 \AA$ is slightly longer than the rest of the $\mathrm{B}-\mathrm{B}$ bonds. Thus, the incoming $\mathrm{H}_{2}$ bond dissociates forming metal hydrides in TS3. Chaudret et al. have previously reported that short $\mathrm{Ru}-\mathrm{H}$ bond lengths are common in ruthenium-hydrogen chemistry [22-25].

\section{Activation energy}

The Gibbs free energies $(\Delta G)$ for TS1 and TS2 indicate that the elimination/addition reaction of $\mathrm{H}_{2}$ occurs through activation of the $\sigma_{\mathrm{H}-\mathrm{H}}$ bond, whereas the higher activation energy of $70.3 \mathrm{kcal} / \mathrm{mol}$ for TS3 implies that oxidative addition on $\mathrm{Ru}$ is not the reaction 


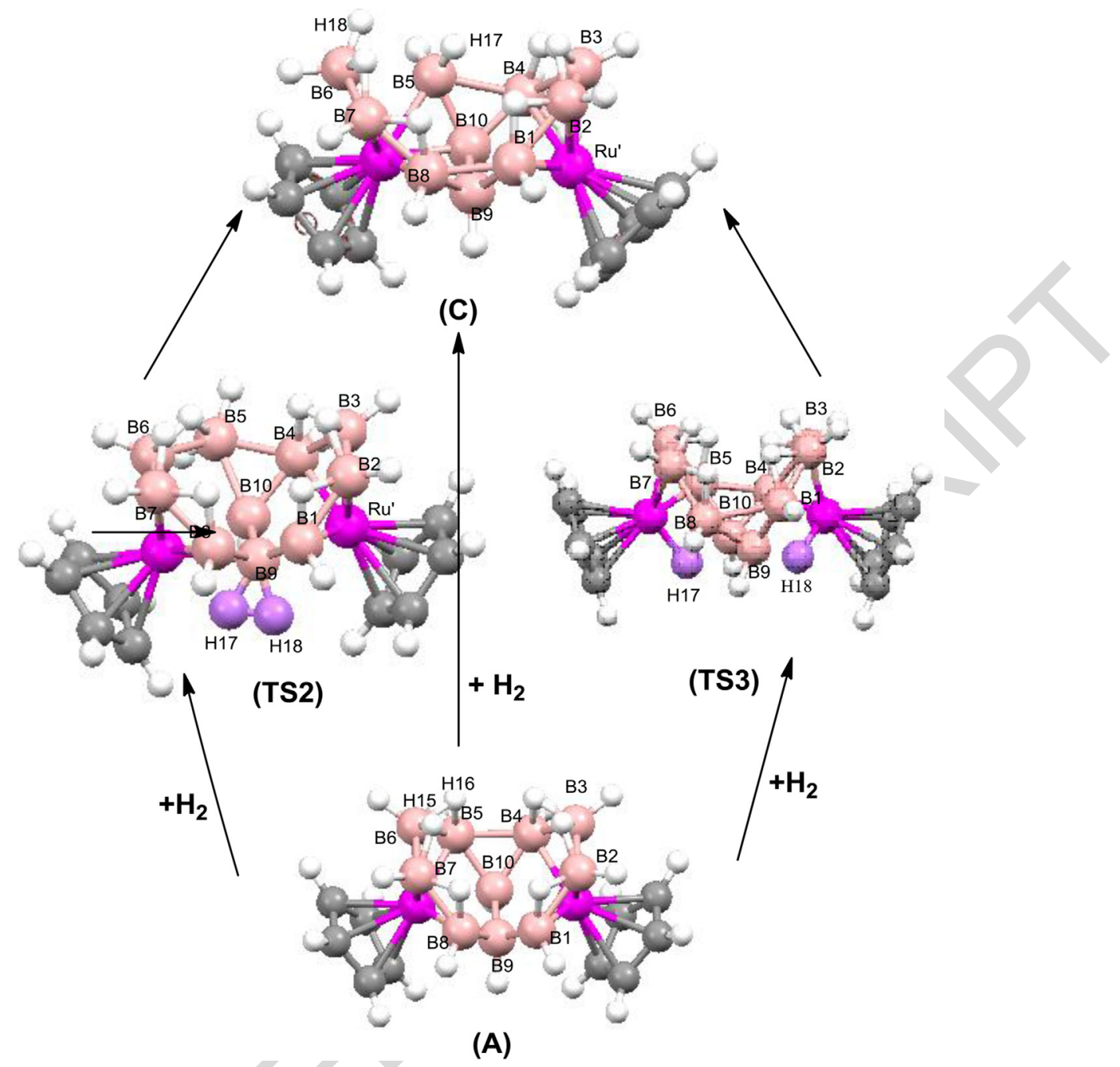

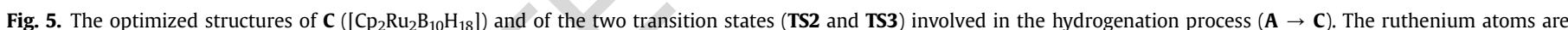

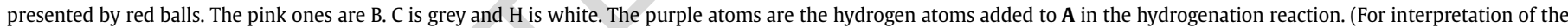
references to colour in this figure legend, the reader is referred to the web version of this article.)

pathway of the hydrogenation addition reaction of $\mathbf{A}$. The reason for this high-energy barrier is basically the energy level crossing of the lone pair orbital and the antibonding $\sigma^{*}$ orbital of $\mathrm{H}_{2}$ [22]. Due to the relatively low activation barriers for TS1 and TS2, we assume that a fast reversible equilibrium might occur through the hydrogenation and dehydrogenation processes via TS1 and TS2. The weak interaction of $\mathrm{H}_{2}$ with the borane ligand might be a key step for achieving a fast and controlled $\mathrm{H}_{2}$ uptake [15,36].

To probe the solvent effect, we carried out single-point calculations of the activation energy of the studied clusters. In the PCM calculations with toluene as solvent, we obtained a lowering in the energy barrier of 3-4 kcal/mol for the studied reactions, which agrees with our previous work [19]. The small reduction in the activation energy suggests the solvent does not change the pathway of the dehydrogenation/hydrogenation reaction, whereas slightly lower barriers are obtained when solvent effects are taken into account.

\section{Related reactions}

The computational study of the cluster stability and the activation of the $\mathrm{H}_{2}$ bond by the ruthenium cluster were extended to the recently synthesized ruthenaboranes $\mathrm{Cp}^{*}{ }_{2} \mathrm{Ru}_{2} \mathrm{~B}_{8} \mathrm{H}_{14}(\mathbf{2})$ and
$\mathrm{Cp}_{2}{ }_{2} \mathrm{Ru}_{2} \mathrm{~B}_{8} \mathrm{H}_{12}$ (3) [16]. In the previous section, we found that the hydrogenation and dehydrogenation do not change substantially the borane structure of $\mathbf{1}$. We therefore carried out similar calculations on models $\mathbf{D}$ and $\mathbf{E}$ used to mimic compounds $\mathbf{2}$ and $\mathbf{3}$ to check if such a behaviour is general in metallaborane chemistry. In these models, the $\mathrm{Cp}^{*}$ units in $\mathbf{2}$ and $\mathbf{3}$ were replaced by $\mathrm{Cp}$ ligands.

\section{The $\mathrm{Cp}_{2} \mathrm{Ru}_{2} \mathrm{~B}_{8} \mathrm{H}_{14}$ structure}

The optimized $\mathrm{Cp}_{2} \mathrm{Ru}_{2} \mathrm{~B}_{8} \mathrm{H}_{14}$ model cluster $\mathbf{D}$ is drawn in Fig. 6 . Selected bond distances are gathered in Table 2. The molecular structure of $\mathbf{D}$ belongs to the $C_{2 \mathrm{~h}}$ point group, which is also the approximate symmetry of the crystal structure of the methyl substituted relative (2) [36]. The optimized structure of $\mathrm{Cp}_{2} \mathrm{Ru}_{2} \mathrm{~B}_{8} \mathrm{H}_{14}$ exhibits slightly longer $\mathrm{Ru}-\mathrm{B}$ and longer $\mathrm{Ru}-\mathrm{C}(\mathrm{Cp})$ distances than observed in $\mathrm{Cp}_{2}{ }_{2} \mathrm{Ru}_{2} \mathrm{~B}_{8} \mathrm{H}_{14}$. The metal is pentacoordinated to the borane. D has a HOMO-LUMO gap of $3.52 \mathrm{eV}$. The $\mathrm{Ru}-\mathrm{Ru}$ distance of $3.952 \AA$ is somewhat longer than the experimental one of $3.897 \AA$ [16]. The average of $B-B$ and $R u-B$ bond lengths of $1.833 \AA$ and $2.191 \AA$, respectively, are also somewhat longer than the experimental ones, which are given in parenthesis in Table 2. 


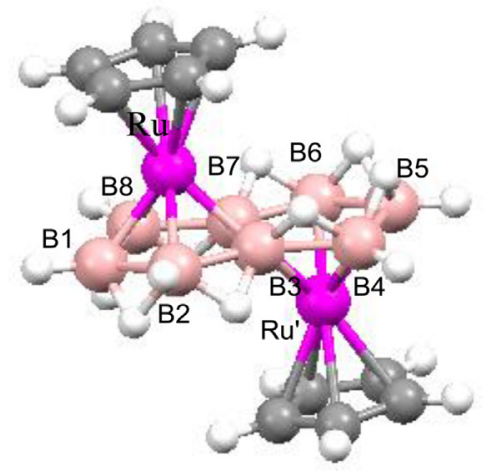

(D)

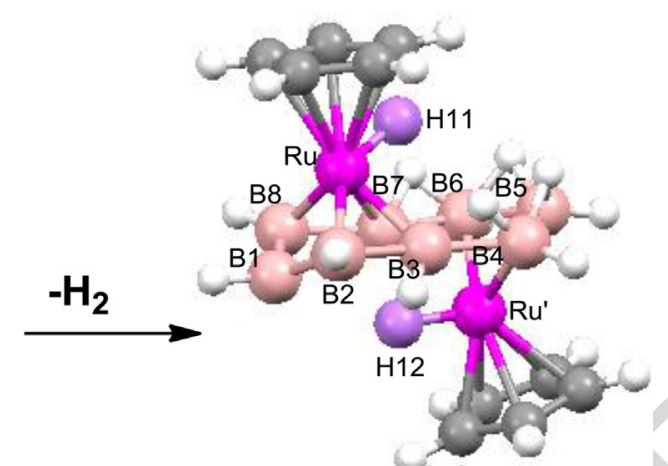

(F)
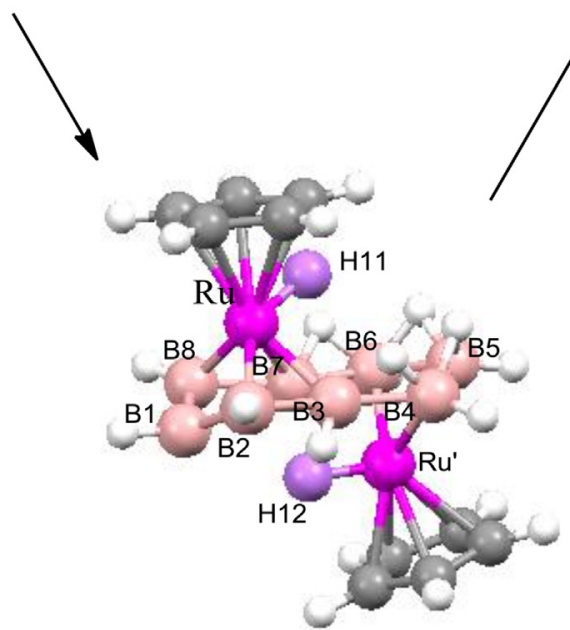

(TS4)

Fig. 6. Molecular structures of $\left[\mathrm{Cp}_{2} \mathrm{Ru}_{2}\left(\mathrm{~B}_{8} \mathrm{H}_{14}\right)\right](\mathbf{D})$, $\left[\mathrm{Cp}_{2} \mathrm{Ru}_{2}\left(\mathrm{~B}_{8} \mathrm{H}_{12}\right)\right](\mathbf{F})$ and TS4. The red balls are Ru and the pink ones are B. $\mathrm{C}$ is grey and $\mathrm{H}$ is white. (For interpretation of the references to colour in this figure legend, the reader is referred to the web version of this article.)

Different $\mathrm{H}_{2}$ elimination reactions of $\left[\mathrm{Cp}_{2} \mathrm{Ru}_{2}\left(\mathrm{~B}_{8} \mathrm{H}_{14}\right)\right]$ D were investigated. The most stable cluster structure for $\mathrm{Cp}_{2} \mathrm{Ru}_{2} \mathrm{~B}_{8} \mathrm{H}_{12}(\mathbf{F})$ has metal hydride bonds (see Fig. 6). The most relevant bond distances for $\mathbf{F}$ are given in Table 2. The $\mathrm{H}_{2}$ elimination reaction of $\mathbf{D}$ yielding $\mathbf{F}$ leads to some structural changes, which mainly occur in the boron skeleton. The B1-B2 and B7-B8 bonds become shorter. The $R \mathbf{R u}-\mathrm{Ru}^{\prime}$ distance of $3.837 \AA$ is slightly shorter than for $\mathbf{D}$. The cluster $\mathbf{F}$ has two short metal-hydride bonds whose distances are

Table 2

Selected optimized bond distances for D, E, F, G, TS4 and TS5. The bond lengths are given in A. Experimental values are given in parentheses.

\begin{tabular}{|c|c|c|c|c|c|c|}
\hline $\mathrm{M}_{2} \mathrm{Cp}_{2} \mathrm{~B}_{8} \mathrm{H}_{n}(n=)$ & $\mathbf{D}(14)$ & $\mathbf{E}(12)$ & $\mathbf{F}(12)$ & $\mathbf{G}(14)$ & TS4 $(\mathbf{D} \rightarrow$ F $)(14)$ & TS5 $(\mathbf{E} \rightarrow \mathbf{G})(14)$ \\
\hline B1-B2 & $1.834(1.820)$ & $1.783(1.778)$ & 1.738 & 2.015 & 1.841 & 2.102 \\
\hline B2-B3 & $1.824(1.823)$ & $1.774(1.772)$ & 1.867 & 1.775 & 1.801 & 1.785 \\
\hline B2-B4 & $1.834(1.827)$ & $2.068(2.014)$ & 1.712 & 2.031 & 1.803 & 2.041 \\
\hline B4-B5 & $1.834(1.827)$ & $1.829(1.817)$ & 1.901 & 1.810 & 1.750 & 1.833 \\
\hline B5-B6 & $1.824(1.820)$ & $1.822(1.806)$ & 1.842 & 1.801 & 1.751 & 1.806 \\
\hline B7-B8 & $1.834(1.827)$ & $1.794(1.799)$ & 1.811 & 1.782 & 1.802 & 1.725 \\
\hline $\mathrm{Ru}-\mathrm{B} 1$ & $2.141(2.107)$ & 2. $285(2.206)$ & 2.319 & 2.591 & 2.312 & 2.634 \\
\hline $\mathrm{Ru}-\mathrm{B} 2$ & $2.128(2.111)$ & $3.333(3.288)$ & 2.071 & 2.192 & 2.215 & 3.701 \\
\hline $\mathrm{Ru}-\mathrm{B} 3$ & $2.175(2.152)$ & $2.324(2.288)$ & 2.123 & 2.156 & 2.291 & 2.412 \\
\hline $\mathrm{Ru}-\mathrm{B} 7$ & $2.175(2.149)$ & $2.136(2.114)$ & 2.132 & 2.135 & 2.294 & 2.196 \\
\hline $\mathrm{Ru}-\mathrm{B} 8$ & $2.128(2.106)$ & $3.179(3.141)$ & 2.124 & 2.167 & 2.151 & 3.221 \\
\hline $\mathrm{Ru}-\mathrm{C}(\mathrm{Cp})$ & $2.334(2.251)$ & $2.321(2.241)$ & 2.281 & 2.331 & 2.331 & 2.315 \\
\hline $\mathrm{Ru}^{\prime}-\mathrm{B} 3$ & 2.175 (2.149) & $3.287(3.271)$ & 2.304 & 2.104 & 2.341 & 3.241 \\
\hline $\mathrm{Ru}^{\prime}-\mathrm{B} 4$ & $2.128(2.106)$ & $2.200(2.173)$ & 2.165 & 2.165 & 2.181 & 2.271 \\
\hline $\mathrm{Ru}^{\prime}-\mathrm{B} 5$ & $2.141(2.107)$ & $2.184(2.150)$ & 2.181 & 2.192 & 2.155 & 2.186 \\
\hline $\mathrm{Ru}^{\prime}-\mathrm{B} 6$ & $2.128(2.111)$ & $2.115(2.108)$ & 2.168 & 2.216 & 2.151 & 2.126 \\
\hline $\mathrm{Ru}^{\prime}-\mathrm{B} 7$ & 2. $175(2.152)$ & $2.132(2.121)$ & 2.305 & - & 2.281 & 2.132 \\
\hline $\mathrm{Ru}^{\prime}-\mathrm{B} 8$ & $2.341(2.249)$ & $2.281(2.238)$ & 2.811 & - & 2.901 & 2.321 \\
\hline $\mathrm{Ru}^{\prime}-\mathrm{C}(\mathrm{Cp})$ & $2.321(2.331)$ & $2.281(2.271)$ & 2.331 & - & 2.351 & 2.345 \\
\hline $\mathrm{Ru}-\mathrm{H} 11$ & - & $1.702(1.602)$ & 1.781 & 1.695 & 1.721 & 1.795 \\
\hline $\mathrm{Ru}^{\prime}-\mathrm{H} 12$ & - & - & 1.891 & 1.663 & 1.819 & 1.763 \\
\hline $\mathrm{Ru}-\mathrm{Ru}^{\prime}$ & 3.952 (3.897) & 2.901 (2.889) & 3.836 & 2.866 & 3.261 & 3.028 \\
\hline
\end{tabular}




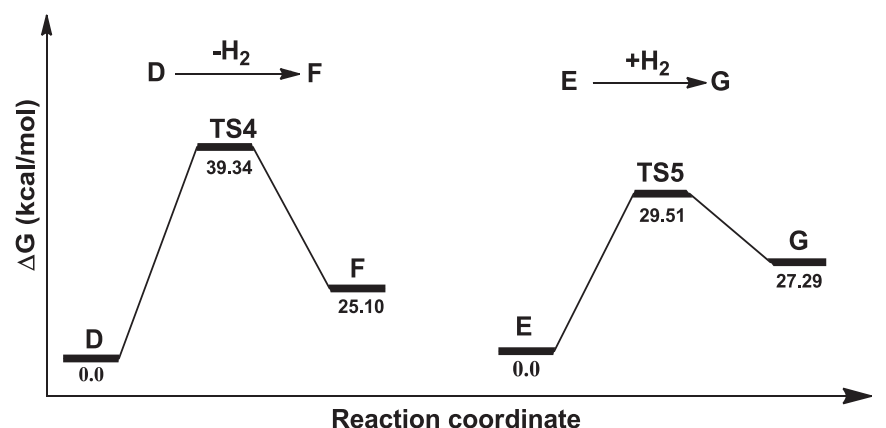

Fig. 7. Relative energies between the optimized structures $\mathbf{D}$ and $\mathbf{F}$ and between $\mathbf{E}$ and $\mathbf{G}$.

$1.781 \AA$ and $1.891 \AA$ for $\mathrm{Ru}-\mathrm{H} 11$ and $\mathrm{Ru}^{\prime}-\mathrm{H} 12$, respectively. The Ru$\mathrm{B} 1$ and $\mathrm{Ru}^{\prime}-\mathrm{B} 3$ bonds break leading to a preservation of the 18electron rules for the complex. The energy difference between $\mathbf{D}$ and F is $25.1 \mathrm{kcal} / \mathrm{mol}$ (see Fig. 7). In the search for the transition state of the $\mathrm{H}_{2}$ elimination reaction from $\mathbf{D}$ to $\mathbf{F}$, we found one transition state (TS4) involving metal-hydride bonds. The $\mathrm{Ru}-\mathrm{H} 11$ and $\mathrm{Ru}^{\prime}-\mathrm{H} 12$ distances are $1.721 \AA$ and $1.819 \AA$, respectively. The activation barrier of TS4 from $\mathbf{D}$ to $\mathbf{F}$ and from $\mathbf{F}$ to $\mathbf{D}$ are $39.3 \mathrm{kcal} / \mathrm{mol}$ and $14.2 \mathrm{kcal} / \mathrm{mol}$ respectively. The calculations suggest that the hydrogenation reaction does not involve any oxidative addition or reductive elimination in this cluster. For F and TS4, the $\mathrm{Cp}-\mathrm{M}$ bonding does not change much resulting in a similar structure as for $\mathbf{D}$.
The $C p_{2} R u_{2}\left(B_{8} H_{12}\right)$ structure

Since the crystallographic [16] and electronic [17] structures of $\left(\mathrm{C}_{5} \mathrm{Me}_{5}\right)_{2} \mathrm{Ru}_{2} \mathrm{~B}_{8} \mathrm{H}_{12}$ (3) are known, we focus here on the hydrogenation reaction with $\mathrm{Cp}_{2} \mathrm{Ru}_{2} \mathrm{~B}_{8} \mathrm{H}_{12}$ (E) as starting structure for the calculations. The molecular structure of $\mathbf{E}$ was also optimized. Selected bond distances are compared to experimental values in Table 2. The largest deviations between calculated and observed bond distances for $\mathbf{E}$ occur for $\mathrm{Ru}-\mathrm{B} 2, \mathrm{Ru}^{\prime}-\mathrm{B} 3$, and $\mathrm{B} 2-\mathrm{B} 4$. $\mathbf{E}$ has only one short hydride-metal bond, namely Ru-H11 which is $1.702 \AA$ long. The $\mathrm{Ru}-\mathrm{Ru}^{\prime}$ distance in $\mathbf{E}$ of $2.889 \AA$ is short as compared to the experimental one.

We also studied the $\mathrm{H}_{2}$ addition reaction of $\mathbf{E}$ yielding the stable structure $\mathrm{Cp}_{2} \mathrm{Ru}_{2} \mathrm{~B}_{8} \mathrm{H}_{14}$, which is labelled $\mathbf{G}$ in Fig. 8. The most relevant bond lengths of the optimized structure of $\mathbf{G}$ are given in Table 2. The optimization of the $\mathbf{G}$ yielded a structure with two metal-hydride bonds of $1.695 \AA$ and $1.663 \AA$ and broken Ru-B bonds. The transition state (TS5) between $\mathbf{E}$ and $\mathbf{G}$ was obtained using IRC. TS5 has also two short metal-hydride bonds of $1.721 \AA$ and $1.819 \AA$ and broken Ru-B bonds. The bond distances are given in Table 2 and the molecular structure is shown in Fig. 8. The energy levels in Fig. 7 show that $\mathbf{G}$ is $27.3 \mathrm{kcal} / \mathrm{mol}$ higher in energy than $\mathbf{E}$ and TS5 is $29.5 \mathrm{kcal} / \mathrm{mol}$ above $\mathbf{E}$ and only $2.2 \mathrm{kcal} / \mathrm{mol}$ above $\mathbf{G}$. The obtained energy barrier at TS5 suggests that $\mathbf{E}$ and $\mathbf{G}$ might be a good cluster pair for reversible hydrogenation/dehydrogenation reactions and storage of $\mathrm{H}_{2}$.

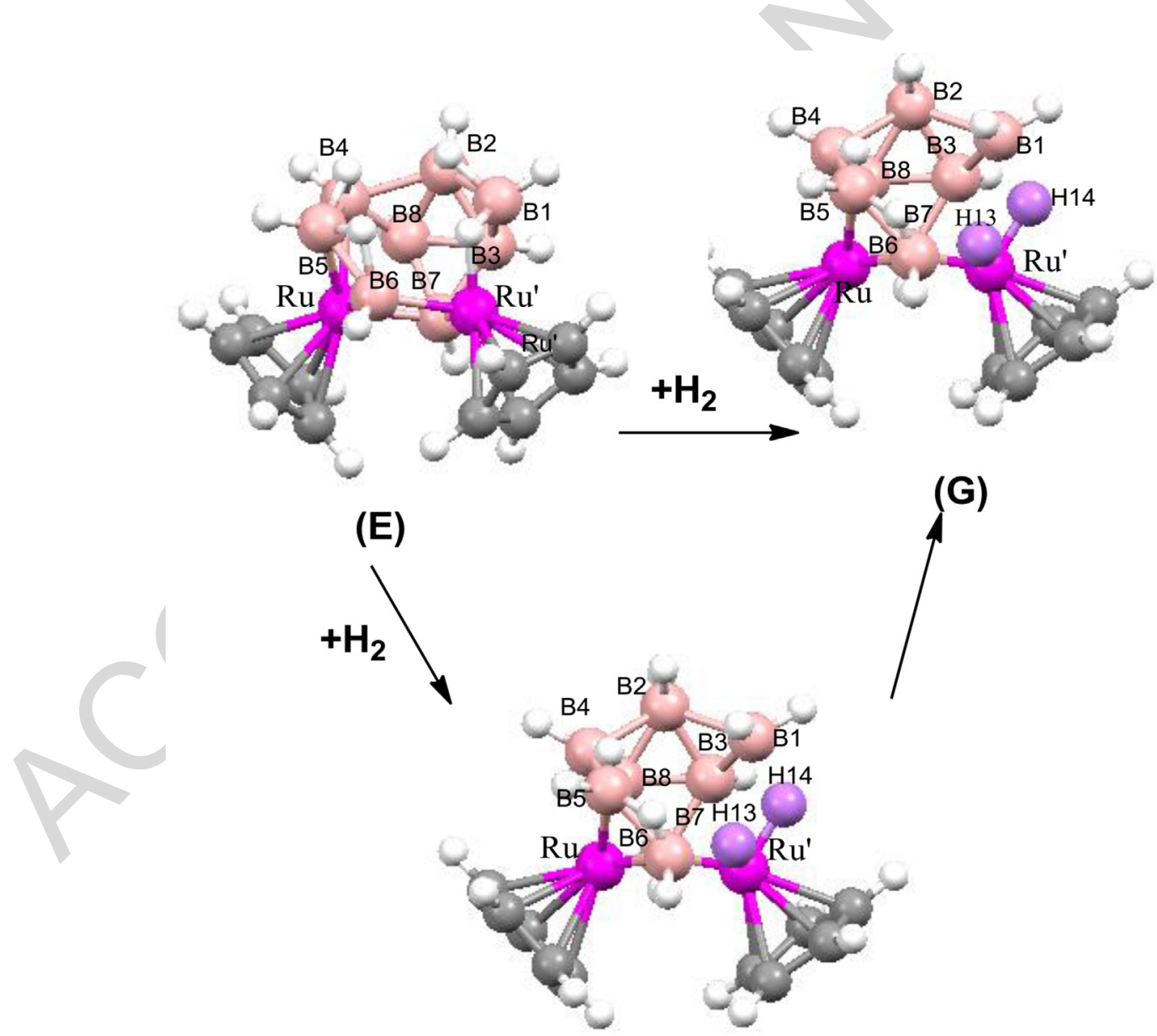

(TS5)

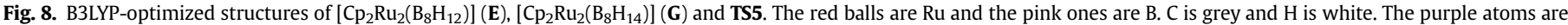

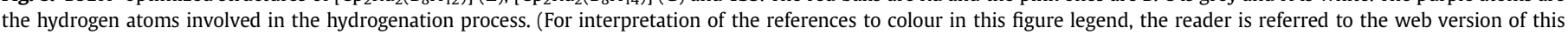
article.) 


\section{Conclusions}

Hydrogenation and dehydrogenation processes of ruthenaborane clusters have been studied computationally at the DFT/B3LYP level. Calculations show different bonding modes of the added $\mathrm{H}_{2}$ molecule to the investigated clusters.

Optimization of the ruthenaborane clusters yielded both $\eta^{2}-\mathrm{H}_{2}$ coordinated as well as formation of metal-hydride $(\mathrm{Ru}-\mathrm{H})$ bonds. Activation pathways of the $\mathrm{H}-\mathrm{H}$ bond by ruthenaboranes were also analysed. Calculations of the energy profiles yielded $\mathrm{H}_{2}$ addition and elimination energies of $14-27 \mathrm{kcal} / \mathrm{mol}$ for the studied (A, B, D and $\mathbf{E}$ ) clusters. The calculated $\mathrm{H}_{2}$ elimination energy of $\mathbf{D}$ yielding $\mathbf{F}$ is $25 \mathrm{kcal} / \mathrm{mol}$. The obtained results indicate that molecular hydrogen can be added to electron-deficient metallaborane clusters with high hydride content such as $\mathrm{Cp}_{2}{ }_{2} \mathrm{Ru}_{2} \mathrm{~B}_{10} \mathrm{H}_{16}$ and $\mathrm{Cp}_{2}{ }_{2} \mathrm{Ru}_{2} \mathrm{~B}_{8} \mathrm{H}_{12}$. However, whereas the free energies of the $\mathrm{H}_{2}$ uptake reactions appear to be nearly acceptable, the activations barrier are too large for expecting the reactions to occur at room temperature or under moderate heating. Work is in progress in our group to design related systems with lower activation barriers and reaction free energies. Nevertheless, this study suggests that these kinds of clusters may be a good conceptual starting point for the development of metal-hydride based materials suitable for hydrogen storage or of molecular catalysts for hydrogen storage processes $[37,38]$.

\section{Acknowledgement}

We thank the CNRS (France), the CNRST (Morocco) Convention: Chimie:13-10, the Indo-French Centre for Promotion of Advanced Research (IFCPAR, Project No. 4405-1) and the University of Helsinki for their financial support. This research was also supported by the Academy of Finland through Project 137460 and its Computational Science Research Programme (LASTU/258258).

\section{Appendix A. Supplementary data}

Supplementary data related to this article can be found at http:// dx.doi.org/10.1016/j.jorganchem.2014.03.001.

\section{References}

[1] J. Graetz, Chem. Soc. Rev. 38 (2009) 73.

2] S. Orimo, Y. Nakamori, J.R. Eliseo, A. Zuttel, C.M. Jensen, Chem. Rev. 107 (2007) 4111.

[3] C.W. Hamilton, R.T. Baker, A. Staubitz, I. Manners, Chem. Soc. Rev. 38 (2009) 279.

[4] A.W.C. van der Berg, C.O. Arean, Chem. Commun. (2008) 668.

[5] S.A. Shevlin, Z.X. Guo, Chem. Soc. Rev. 38 (2009) 211.

[6] T. Matsunagaa, F. Buchtera, K. Miwac, S. Towatac, S. Orimod, A. Zuttel, Renew. Energy 33 (2008) 193.

[7] J. Yang, A. Sudik, D.J. Siegel, D. Halliday, A. Drews, R.O. Carter III, C. Wolverton, G.J. Lewis, J.W.A. Sachtler, J.J. Low, S.A. Faheem, D.A. Lesch, V. Ozolins, Angew. Chem. Int. Ed. 47 (2008) 882.

[8] D.A. Dixon, M. Gutowski, J. Phys. Chem. A 109 (2005) 5129.

[9] Y. Nakamori, H.-W. Li, M. Matsuo, K. Miwa, S. Towata, S. Orimo, J. Phys. Chem. Solids 69 (2008) 2292

[10] F.H. Stephens, V. Ponns, T.R. Baker, Dalton Trans. (2007) 2613.

[11] U. Eberle, M. Felderhoff, F. Sch]th, Angew. Chem. Int. Ed. 48 (2009) 6608.

[12] F. de Montigny, R. Macias, B.C. Noll, T.P. Fehlner, K. Costuas, J.-Y. Saillard, J.F. Halet, J. Am. Chem. Soc. 129 (2007) 3392.

[13] S.B. Sun, M.L. McKee, Inorg. Chem. 52 (2013) 5962.

[14] S. Ghosh, B.C. Noll, T.P. Fehlner, Angew. Chem. Int. Ed. 44 (2005) 2916.

[15] M. Rochdi, H. Rabaa, S. Ghosh, J.-Y. Saillard, J.F. Halet, Polyhedron 43 (2012) 31.

[16] S. Ghosh, A.M. Beatty, T.P. Fehlner, Angew. Chem. Int. Ed. 42 (2003) 4678.

[17] L. Guennic, H. Jiao, S. Kahal, J.-Y. Saillard, J.-F. Halet, S. Ghosh, M. Shang, A.M. Beatty, A.L. Rheingold, T.P. Fehlner, J. Am. Chem. Soc. 126 (2004) 3203.

[18] M.T. Kelly, Struct. Bonding 141 (2011) 169.

[19] G.J. Kubas, Metal Dihydrogen and $\sigma$ Bond Complexes: Structure, Theory and Reactivity, Kluwer Academic/Plenium, New York, 2001.

[20] G.J. Kubas, Chem. Rev. 107 (2007) 2613.

[21] H. Rabaâ, J.-Y. Saillard, R. Hoffmann, J. Am. Chem. Soc. 108 (1986) 4327.

[22] A.K. Kandalam, B. Kiran, P. Jena, J. Phys. Chem. C 112 (2008) 6181.

[23] G. Alcaraz, M. Grellier, S. Sabo-Etienne, Acc. Chem. Res. 42 (2009) 1640.

[24] I. Atheaux, F. Delpech, B. Donnadieu, S. Sabo-Etienne, B. Chaudret, K. Hussein, J.C. Barthelat, T. Braun, S.B. Duckett, R.N. Perutz, Organometallics 21 (2002) 5347.

[25] T. Arliguie, B. Chaudret, R.H. Morris, A. Sella, Inorg. Chem. 27 (1988) 598.

[26] M.J. Frisch, et al., Gaussian 09, Revision A.1, Gaussian, Inc., Wallingford CT, 2009.

[27] C. Lee, W. Yang, R.G. Parr, Phys. Rev. B 37 (1988) 785.

[28] A.D. Becke, J. Chem. Phys. 98 (1993) 5648.

[29] W.J. Stevens, H. Basch, M. Krauss, J. Chem. Phys. 81 (1984) 6026.

[30] C. Peng, H.B. Schlegel, J. Israel, J. Chem. Phys. 33 (1993) 449.

[31] C. Peng, P.Y. Ayala, H.B. Schlegel, M.J. Frisch, J. Comput. Chem. 17 (1996) 49.

[32] G. Scalmani, M.J. Frisch, J. Chem. Phys. 132 (2010) 114110.

[33] T.P. Fehner, J.-F. Halet, J.-Y. Saillard, Molecular Cluster, Cambridge Univ. Press., Cambridge, UK, 2007.

[34] D.M.P. Mingos, D.J. Wales, Introduction to Cluster Chemistry, Prentice-Hall, Englewood Cliffs, 1990

[35] M. Touil, B. Bechem, A.S.K. Hashmi, B. Engels, M.A. Omary, H. Rabaâ, J. Mol. Struct. Theochem. 975 (2010) 21.

[36] B. Boucher, S. Ghosh, J.-F. Halet, S. Khalal, J.-Y. Saillard, J. Organomet. Chem. 721 (2012) 167.

[37] R.D. Adams, B. Captain, Angew. Chem. Int. Ed. 47 (2008) 252.

[38] R.H. Crabtree, Organometallics 30 (2011) 17.

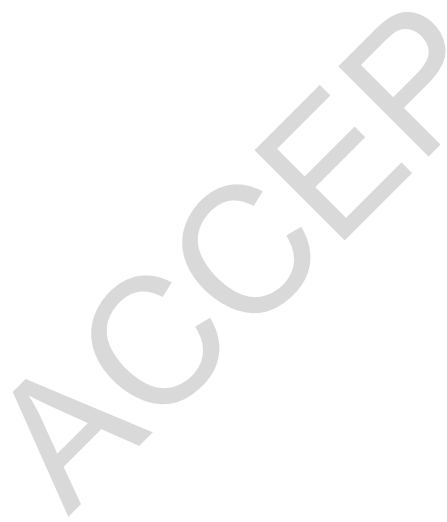

